\title{
NITROGENASE ACTIVITY OF BEIJERINCKIA DERXII IS PRESERVED UNDER ADVERSE CONDITIONS FOR ITS GROWTH
}

\author{
Heloiza R. Barbosa ${ }^{1 *}$; Marcos A. Moretti ${ }^{1}$; Daniela S. Thuler ${ }^{1}$; Elisabeth F.P. Augusto ${ }^{2}$
}

${ }^{1}$ Departamento de Microbiologia, Instituto de Ciências Biomédicas, Universidade de São Paulo, São Paulo, SP, Brasil. ${ }^{2}$ Grupo de Biotecnologia, Departamento de Química, Instituto de Pesquisa e Tecnologia - IPT, São Paulo, SP, Brasil.

Submitted: October 30, 2001; Returned to authors for corrections: April 08, 2002; Approved: September 24, 2002

\begin{abstract}
In order to evaluate the response of Beijerinckia derxii ICB-10 to different environmental factors, growth curves and specific nitrogenase activity were studied. Tested conditions were as follows: a) media with different $\mathrm{pH}$ values (2.5, 2.8, 4.2 and 5.7); b) medium supplemented with $230 \mu \mathrm{M}$ aluminium sulphate; c) media with two different potassium phosphate concentrations (50 mM and $100 \mathrm{mM})$; d) shaken or still cultures; e) medium supplemented with $40 \mathrm{mM}$ sodium thiosulphate. Growth curves and specific nitrogenase activity at $\mathrm{pH} 4.2$ were closely similar to those for cultures at $\mathrm{pH} 5.7$ (standard condition), whereas no growth occurred at $\mathrm{pH}$ 2.5. Changes in growth curves and/or specific nitrogenase activity were observed under the following conditions: I) $\mathrm{pH} 2.8$ (decrease in initial CFU number, reduction of maximum specific growth rate, reduced number of generations and stimulation of nitrogenase activity), II) presence of aluminium (early death phase), III) $50 \mathrm{mM} \mathrm{PO}_{4}{ }^{3-}$ (reduction of maximum specific growth rate), IV) $100 \mathrm{mM} \mathrm{PO}_{4}{ }^{3-}$ (reduction of both number of generations and maximum specific growth rate as well as early death phase), $\mathrm{V}$ ) low $\mathrm{O}_{2}$ availability (increasing nitrogenase activity), and VI) presence of thiosulphate (reduction of maximum specific growth rate; early death phase and high stimulation of nitrogenase activity). The data obtained showed the high variability of the cell growth response to environmental factors. Nitrogenase activity was always preserved even when population growth was affected.
\end{abstract}

Key words: Beijerinckia, nitrogenase, nitrogen fixation, growth, environmental factors

\section{INTRODUCTION}

The importance of the nitrogen cycle in productivity of the biosphere has caused many authors to focus their attention on nitrogen fixation, which is its rate-determining step of the $\mathrm{N}$ cycle (18). Consequently, considerable research effort has been devoted to understand and overcoming inefficiencies in this process.

Environmental factors may repress nitrogen-fixing bacteria. They may act on physiological properties restricting growth or inhibiting the nitrogenase activity, thus, lowering the contribution of these microorganisms to the environment. Several authors have studied the effects of chemical factors both on axenic cultures or on the environment. $(12,14,19,21)$.
Free-living nitrogen-fixing bacteria from the genus Beijerinckia are commonly isolated from lateritic tropical soils. Laterization leads to accumulation of aluminium, iron, titanium and manganese, while there is simultaneously a leaching away of bases such as calcium, potassium, magnesium and sodium. The low pHs values, generally found in these soils, are responsible for low phosphate and nitrogen availability. (7). Considering these characteristics, Becking (8) showed that $\mathrm{pH}$ 3.0 is the lowest value in which the genus Beijerinckia is able to grow and fix nitrogen; but he did not determine the effect of $\mathrm{pH}$ on growth in quantitative terms. The same author also showed that $\mathrm{Al}^{3+}, \mathrm{PO}_{4}^{3-}$ and other minerals $\left(\mathrm{Ca}^{2+}, \mathrm{K}^{+}, \mathrm{Fe}^{2+}, \mathrm{Fe}^{3+}\right.$ etc) may function as nutrients or inhibitors of Beijerinckia and Azotobacter growth. The actual effect of these minerals depends

\footnotetext{
* Corresponding author. Mailing address: Departamento de Microbiologia, Instituto de Ciências Biomédicas, Universidade de São Paulo. Av. Prof. Lineu Prestes, 1374, Cidade Universitária, 05508-900, São Paulo, SP, Brasil. Fax: (+5511) 3818-7354. E-mail: hrbarbos@.icb.usp.br
} 
on the type of element, its concentration, the $\mathrm{pH}$ of the medium in which the effect of those elements was tested and the microorganism itself; since nitrogenase activity was determined only indirectly on the basis of the nitrogen incorporated by bacterial cells, the relation between this enzyme and cell physiology was not investigated.

Oxygen is one of the most important factors interfering with nitrogenase activity. Due to nitrogenase $\mathrm{O}_{2}$-lability, $\mathrm{N}_{2}$-fixing organisms require low oxygen pressures or protective mechanisms to maintain the enzyme activity (18). Excessive $\mathrm{O}_{2}$ inhibits nitrogenase activity, but lack of this element results in a reduction of bacterial growth (11). In Beijerinckia derxii strain ICB-10 the mucous layer functions as a morphological protective mechanism that allows nitrogenase activity under high agitation (4). However, there are no data concerning the enzyme activity under low conditions of oxygen availability.

The association of a Beijerinckia with the leaching bacterium Thiobacillus ferrooxidans was found to enhance the rate and the extent of copper and nickel ore leaching, demonstrating that nitrogen fixation can be important in bioextractive metallurgy $(22,24)$. However, there is no data on the interference of elements such as sulphur compounds, not commonly occurring in soil, but present in leaching processes, on the physiology of Beijerinckia.

Whatever the potential applications of Beijerinckia may be, very little information is available about the adverse effect of intrinsic soil characteristics (lack of nutrients, excessive amounts of inhibitors, etc.) and leaching conditions (low $\mathrm{pH}$ and high mineral concentrations) on the bacterial physiology.

The aim of the present study was to verify the possible effects of some environmental factors on the growth and nitrogenase activity of Beijerinckia derxii strain ICB-10. Nitrogenase activity profiles in cultures grown at low $\mathrm{pH}$ values (2.8 and 4.2), with different phosphate concentrations, in the presence of aluminium and $\mathrm{S}_{2} \mathrm{O}_{3}{ }^{2-}$ and low $\mathrm{O}_{2}$ availability were drawn to establish a correlation between nitrogenase activity profiles and growth curves obtained under the same growth conditions.

\section{MATERIALS AND METHODS}

\section{Microorganism}

The microorganism, identified as Beijerinckia derxii - ICB10 (ATCC 33962) (2) was isolated from latosol-red yellow soil under shrubland cover in Pirassununga, São Paulo, Brazil. Some chemical characteristics of the soil were: $\mathrm{pH} 4.2,0.77 \%$ organic matter, scarcity of phosphates and high aluminium concentrations that predominantly ranged from 6.9 to $14.4 \mathrm{mg}$ per $100 \mathrm{~g}$ of soil, although lower levels may also be present (15).

\section{Culture media and conditions}

Basic medium (medium B) consisted of (g.L $\left.{ }^{-1}\right): \mathrm{K}_{2} \mathrm{HPO}_{4}$ $0.10 ; \mathrm{CaCl}_{2} .2 \mathrm{H}_{2} \mathrm{O}-0.02 ; \mathrm{MgSO}_{4} .7 \mathrm{H}_{2} \mathrm{O}-0.2 ; \mathrm{Na}_{2} \mathrm{MoO}_{4} .2 \mathrm{H}_{2} \mathrm{O}-$
$0.002 ; \mathrm{KH}_{2} \mathrm{PO}_{4}-0.30 ; \mathrm{FeCl}_{3} .6 \mathrm{H}_{2} \mathrm{O}-0.01 ; \mathrm{CoCl}_{2} . \mathrm{H}_{2} \mathrm{O}-0.0008$ and glucose - 10; pH 5.7. For solid medium, 12 g.L $\mathrm{L}^{-1}$ of agar were added to liquid basic medium.

The experimental conditions were as follows: condition $\boldsymbol{A}$ was the standard one, where basic medium was used to grow shaken cultures at $200 \mathrm{rpm}$ in a model G-25 rotary shaker "New Brunswick Sci Co", N.J., U.S.A. The other conditions were modifications of condition A. In condition $\boldsymbol{B}, \boldsymbol{C}$ and $\boldsymbol{D}$ the $\mathrm{pH}$ of the media were 2.5, 2.8 and 4.2, respectively. In condition $\boldsymbol{E}$, $230 \mu \mathrm{M} \mathrm{Al}{ }_{2}\left(\mathrm{SO}_{4}\right)_{3}$ was added and $\mathrm{pH}$ was 4.2 . In conditions $\boldsymbol{F}$ and $\boldsymbol{G}$ the phosphate concentrations were $50 \mathrm{mM}$ and $100 \mathrm{mM}$, respectively. In condition $\boldsymbol{H}$, the culture was not agitated. In condition I, $40 \mathrm{mM} \mathrm{Na} \mathrm{S}_{2} \mathrm{O}_{3}$ was added. The $\mathrm{pH}$ of the media was adjusted with $0.1 \mathrm{M} \mathrm{HCl}$ in a model $\mathrm{H}-5$ pHmeter, "Horiba" Kyoto, Japan, before sterilization $\left(121^{\circ} \mathrm{C}, 20 \mathrm{~min}\right)$ and checked afterwards. In conditions $\mathrm{F}, \mathrm{G}, \mathrm{H}$ and $\mathrm{I}$ the $\mathrm{pH}$ was 5.7. The $\mathrm{Al}_{2}\left(\mathrm{SO}_{4}\right)_{3}$ concentration was the same as employed by Becking (8) including the eventual contaminants in the standard medium.

\section{Sampling}

A $72 \mathrm{~h}$ culture grown on $\mathbf{B}$ medium was used as inoculum at $5 \%(\mathrm{v} / \mathrm{v})$ concentration. Cultures were grown in $500 \mathrm{~mL}$ conical flasks containing $100 \mathrm{~mL}$ of medium and incubated at $30^{\circ} \mathrm{C}$. Samples were taken periodically for evaluation of colony forming units (CFU) by the drop method (5) and of nitrogenase activity by the acetylene reduction method (23). In the nitrogenase activity assays, $1.0 \mathrm{~mL}$ of the culture was added to a tube with a rubber stopper and $10 \%$ of the gas phase was withdrawn with a syringe and replaced with acetylene. The flasks were incubated for $2 \mathrm{~h}$ at $30^{\circ} \mathrm{C}$ in a model R-25 reciprocating shaker "New Brunswick Sci Co", N.J. U.S.A. Ethylene $\left(\mathrm{C}_{2} \mathrm{H}_{4}\right)$ was measured using a model GC-14A gas chromatograph "Shimadzu", Kyoto, Japan equipped with stainless steel columns packed with Porapak $\mathrm{N}$ and a hydrogen flame ionization detector. The nitrogenase activity was expressed as the mean of three determinations. Using the area values obtained from the chromatogram, specific nitrogenase activity (A) was calculated according to the expression:

\[ \mathbf{A}=\frac{\mathbf{n}_{\mathrm{A}} \cdot \mathbf{V}_{\mathbf{f}}}{\mathbf{t . C F U} \cdot \mathbf{V}_{\mathrm{a}}} \]
$\mathrm{V}_{\mathrm{f}}=$ Flask volume $(\mathrm{L}) ;$
$\mathrm{V}_{\mathrm{a}}=$ sample volume $(\mathrm{L}) ;$
$\mathrm{t}=$ reaction time $(\mathrm{h}) ;$
$\mathrm{CFU}=$ colony forming units. $\mathrm{mL}^{-1} ;$
$\mathrm{n}_{\mathrm{A}}$, the number of mols of each sample, was obtained as follows;
$\mathrm{n}_{\mathrm{A}}=\mathrm{n}_{\mathrm{B}}$. sample area / $\mathrm{C}_{2} \mathrm{H}_{4}$ standard area;
$\mathrm{C}_{2} \mathrm{H}_{4}$ standard area was a mean of three chromatographic
determinations;
$\mathrm{n}_{\mathrm{B}}=\mathrm{n} /$ standard flask volume;
$\mathrm{n}$, the number of mols of $\mathrm{C}_{2} \mathrm{H}_{4}$ standard, was calculated using
the expression $\mathrm{n}=\mathrm{P} \mathrm{V} / \mathrm{R} \mathrm{T} ;$
$\mathrm{P}=$ pressure in atm;


$\mathrm{V}=$ volume $(\mathrm{L})$ of $\mathrm{C}_{2} \mathrm{H}_{4}$ used to prepare the standard flask;

$\mathrm{R}=$ the gas constant, $0.082 \mathrm{~atm} \cdot \mathrm{L} \cdot \mathrm{K}^{-1} \cdot \mathrm{mol}^{-1}$;

$\mathrm{T}=$ temperature in ${ }^{\circ} \mathrm{K}$.

Linear regression fittings (least square method) were applied to $\ln$ (CFU number) curves in order to obtain maximum growth rate values $\left(\mu_{\max }\right)$ for each condition $(17)$. The same methodology was used to determine the specific death rate $\left(\mathrm{K}_{\mathrm{D}}\right)$ during the death phase.

The Student t-test $(\alpha=0.05)$ was applied in order to determine significant differences between the mean $\mu_{\max }$ value of each environmental condition tested and the standard condition (condition A). The number of generations (n) was calculated according to the expression:

$$
\begin{aligned}
& \mathrm{n}=\frac{\left(\mathrm{t}_{\mathrm{f}}-\mathrm{t}_{0}\right) \cdot \mu_{\mathrm{MAX}}}{\ln 2} \\
& \mathrm{t}_{\mathrm{f}}=\text { time when CFU is maximum; } \\
& \mathrm{t}_{\mathrm{o}}=\text { initial time. }
\end{aligned}
$$

\section{RESULTS}

\section{Influence of pH}

Fig. 1 and Table 1 show the growth and specific nitrogenase activity profiles of $B$. derxii strain ICB-10 under conditions A, $\mathrm{C}$, and D (see Material and Methods). At pH 5.7 (condition A) the microorganism presented the following characteristics: $\mu_{\max }=$ $0.0592 \mathrm{~h}^{-1}$, a stationary phase observed from 70 to 260 hours, no

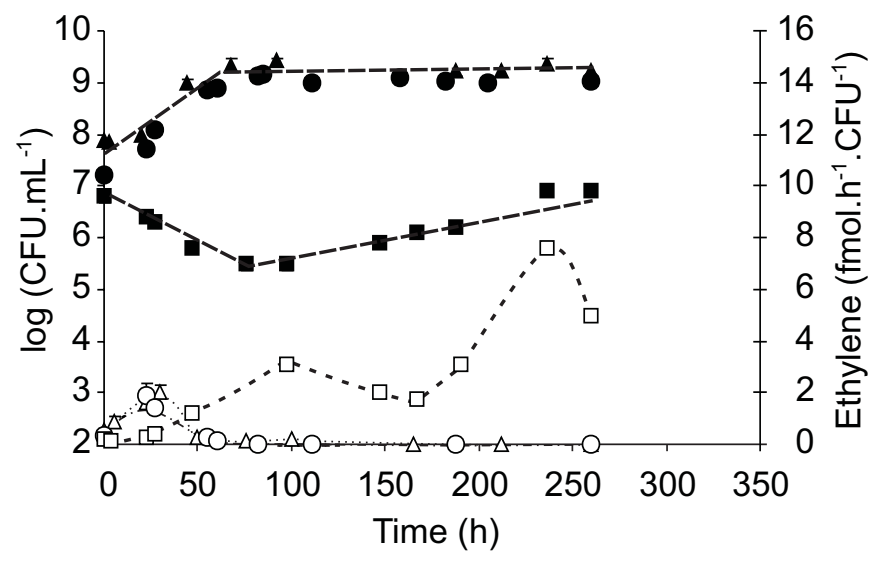

Figure 1: Growth measured as CFU.mL $\mathrm{m}^{-1}$ (closed symbols) and specific nitrogenase activity measured as fmol.h ${ }^{-1}$.CFU ${ }^{-1}$ ethylene (open symbols) curves of $B$. derxii grown in media with different $\mathrm{pH}$ values, i.e., $2.8(\boldsymbol{\square}), 4.2(\mathbf{O})$ and $5.7(\mathbf{\Delta})$ (conditions $\mathrm{C}, \mathrm{D}$ and $\mathrm{A}$ ).

death phase, and $n=5.1$. The specific nitrogenase activity, restricted to the exponential growth phase, showed a single peak with a maximum value of about $2.0 \mathrm{fmol}^{-1}{ }^{-1} \mathrm{CFU}^{-1} \mathrm{C}_{2} \mathrm{H}_{4}$. No growth occurred at $\mathrm{pH} 2.5$ (condition $\mathrm{B}$ ). The characteristic pattern of the growth curve at $\mathrm{pH} 2.8$ (condition $C$ ) showed a decline of the initial CFU number up to 80 hours followed by an increase in the remaining population, reaching the initial CFU

Table 1. Characteristics of $B$. derxii growth curves under different environmental conditions: maximum growth rates ( $\left.\mu_{\max }\right)$, death

\begin{tabular}{|c|c|c|c|c|c|c|c|c|c|}
\hline \multirow{2}{*}{\multicolumn{3}{|c|}{ Experimental Conditions }} & \multicolumn{3}{|c|}{$\mu_{\max }\left(\mathrm{h}^{-1}\right)$} & \multicolumn{3}{|c|}{$\mathrm{K}_{\mathrm{D}}\left(\mathrm{h}^{-1}\right)$} & \multirow{2}{*}{$\begin{array}{c}\text { Number of } \\
\text { generations (n) }\end{array}$} \\
\hline & & & Mean $^{(a)}$ & $\mathrm{S} \mathrm{D}^{(\mathrm{b})}$ & $\mathrm{VC}^{(\mathrm{c})}$ & Mean $^{(a)}$ & $\mathrm{SD}^{(\mathrm{b})}$ & $\mathrm{VC}^{(\mathrm{c})}$ & \\
\hline \multirow{3}{*}{$\mathrm{pH}$} & $\overline{\mathbf{A}}$ & $5.7(6)$ & $0.0592 *$ & 0.0134 & 22.6 & 0 & & - & 5.1 \\
\hline & C & $2.8(3)$ & 0.0198 & 0.0020 & 9.9 & 0 & & - & 3.5 \\
\hline & D & $4.2(5)$ & $0.0611 *$ & 0.0081 & 13.2 & 0 & & - & 6.0 \\
\hline $\begin{array}{c}\mathrm{Al}_{2}\left(\mathrm{SO}_{4}\right)_{3} \\
(\mathrm{M})\end{array}$ & $\mathbf{E}$ & $230(3)$ & $0.0596^{*}$ & 0.0098 & 16.4 & -0.0222 & 0.0021 & 9.3 & 4.8 \\
\hline $\mathrm{PO}_{4}^{3-}$ & $\mathbf{F}$ & $50(2)$ & 0.0375 & 0.0099 & 26.4 & -0.0034 & 0.0004 & 12.1 & 4.7 \\
\hline$(\mathrm{mM})$ & G & $100(2)$ & 0.0268 & 0.0052 & 19.5 & -0.0088 & 0.0016 & 18.2 & 2.1 \\
\hline $\begin{array}{c}\mathrm{Na}_{2} \mathrm{~S}_{2} \mathrm{O}_{3} \\
(\mathrm{mM})\end{array}$ & I & $40(2)$ & 0.0227 & 0.0034 & 15.0 & 0.0294 & 0.0006 & 1.9 & 2.4 \\
\hline
\end{tabular}
rates $\left(\mathrm{K}_{\mathrm{D}}\right)$, and number of generations $(\mathrm{n})$. The results of the replicates of each experiment are expressed as mean $\pm \mathrm{SD}$ (standard deviation) and VC (variation coefficient).

(a) Slope obtained from linear regression fitting (least square method);

(b) Standard deviation;

(c) Coefficient of variation $\mathrm{VC}=\frac{\mathrm{SD}}{\mathrm{Mean}} \times 100$

( ) number of experiments in each condition;

* not significantly different. 
number at a $\mu_{\max }=0.0198 \mathrm{~h}^{-1}$ and $\mathrm{n}=3.5$; the specific nitrogenase activity increased at the beginning of culture, presenting a higher peak than the standard condition during the exponential phase. The growth and specific nitrogenase activity curves at $\mathrm{pH} 4.2$ (condition $D$ ) were very similar to those obtained for condition $\mathrm{A}$; the difference was a higher $\mathrm{n}$ value $(\mathrm{n}=6)$. During the development of the populations, the $\mathrm{pH}$ values of the media did not suffer considerable alterations (about $0.1 \mathrm{pH}$ unity).

\section{Influence of aluminium}

Fig. 2 and Table 1 show that culture growth was partially affected in condition $E$. The $\mu_{\max }$ and $\mathrm{n}$ values were not affected compared to condition D. However, a decline in the number of CFU, with a $K_{D}=-0.0222 \mathrm{~h}^{-1}$, was observed immediately after the end of the exponential phase. Specific nitrogenase activity was not affected in comparison to condition D.

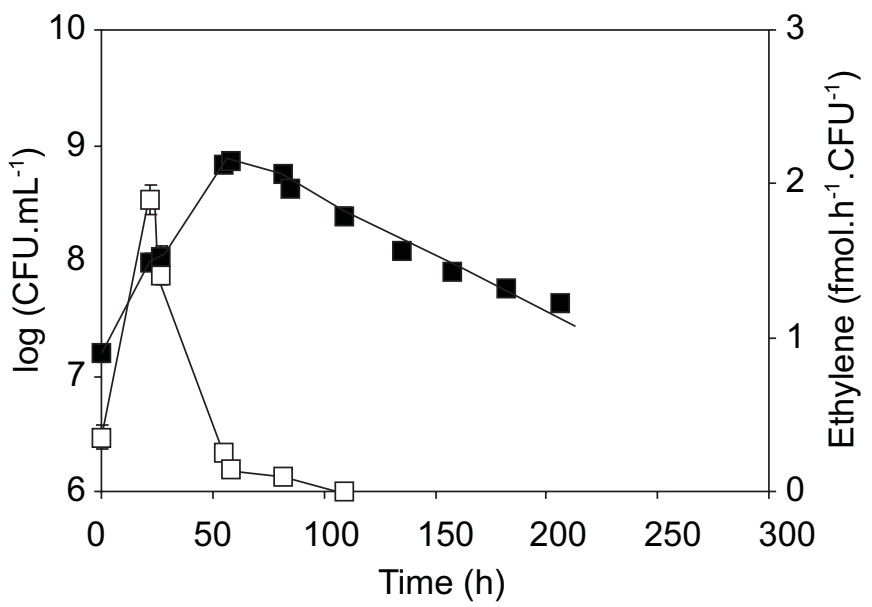

Figure 2: Growth measured as CFU.mL ${ }^{-1}$ (closed symbols) and specific nitrogenase activity measured as fmol.h $\mathrm{h}^{-1}$. $\mathrm{CFU}^{-1}$ ethylene (open symbols) curves of $B$. derxii grown in medium supplemented with $230 \mu \mathrm{M}$ aluminium sulphate, $\mathrm{pH} 4.2$ (condition E).

\section{Influence of phosphate concentration}

Changes in $\mu_{\max }$ values, were proportional to the concentration of phosphate (conditions $F$ and $G$ ) as shown in Fig. 3 and Table 1. Populations grown in condition $F$ showed a $\mu_{\max }=0.0375 \mathrm{~h}^{-1}$, an $n$ value (4.7) close to the standard values and a stable stationary phase up to $180 \mathrm{~h}$, after which they underwent a subtle decline with $K_{D}=-0.0034 h^{-1}$. On the other hand, populations grown in condition G showed a $\mu_{\max }=0.0268 \mathrm{~h}^{-1}$, reached an $\mathrm{n}$ value $=2.1$ and started to decline immediately after the exponential phase with $K_{D}=-0.0088 h^{-1}$. The specific nitrogenase activity for the two tested phosphate concentrations showed very similar profiles which were also similar to the standard profile (Fig. 1).

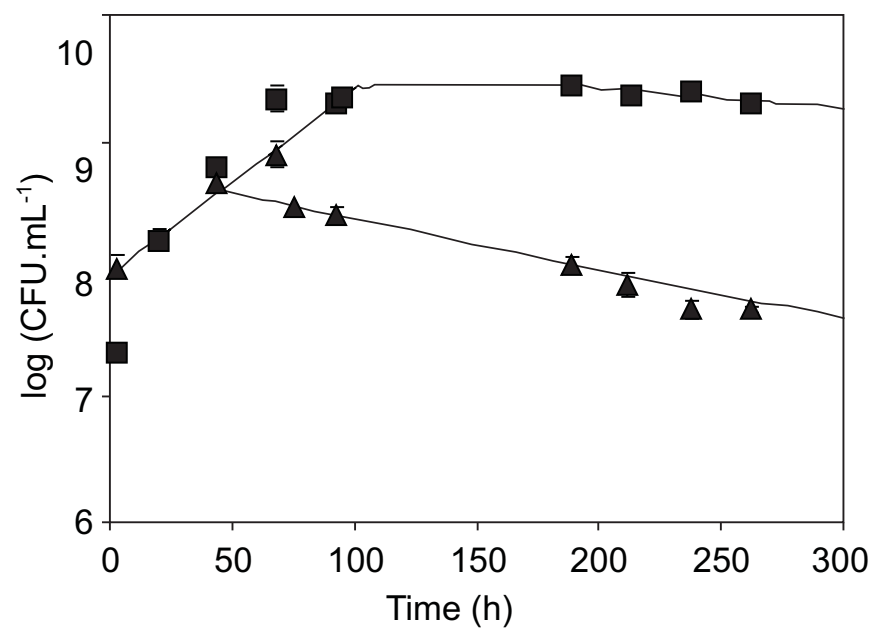

Figure 3: Growth measured as CFU. $\mathrm{mL}^{-1}$ curves of $B$. derxii grown in media containing different phosphate concentrations: $50 \mathrm{mM}(\boldsymbol{\square})$ and $100 \mathrm{mM}(\boldsymbol{\Delta})$ (conditions F and G).

\section{Influence of $\mathrm{O}_{2}$ availability}

Compared to the shaken culture, the unshaken culture (condition $H$ ) presented a practically constant cell number throughout the assay (Fig. 4), although a gradual increase in specific nitrogenase activity was observed; the enzyme activity was still high at the end of the test, being comparable to the peaks observed for the shaken culture.

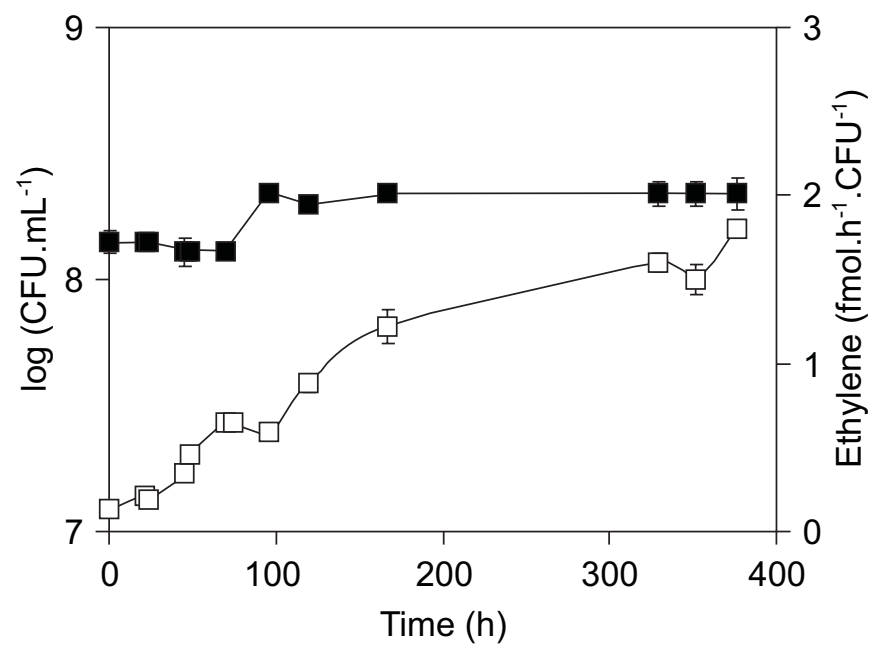

Figure 4: Growth measured as CFU.mL $\mathrm{mL}^{-1}$ (closed symbols) and specific nitrogenase activity measured as fmol.h ${ }^{-1} \cdot \mathrm{CFU}^{-1}$ ethylene (open symbols) curves of $B$. derxii grown in unshaken culture (condition $\mathrm{H})$. 


\section{Influence of sodium thiosulphate}

As indicated by the low $\mu_{\max }$ value $\left(0.0227 \mathrm{~h}^{-1}\right)$, the low $\mathrm{n}$ (2.4) and the establishment of the decline phase after $90 \mathrm{~h}\left(\mathrm{~K}_{\mathrm{D}}=\right.$ $-0.0294 \mathrm{~h}^{-1}$ ) (Table 1), bacterial growth (Fig. 5) was quite affected by the presence of thiosulphate (condition I). The peak of specific nitrogenase activity in the exponential phase was about 9 times higher than that observed under standard conditions. Nevertheless, another peak with a much higher value was observed during the death phase.

Statistically significant differences in $\mathrm{m}_{\max }$ values compared to the standard condition were observed only for the cultures at $\mathrm{pH} 2.8$, at $50 \mathrm{mM}$ and $100 \mathrm{mM}$ phosphate concentrations and in the presence of thiosulphate (Table 1).

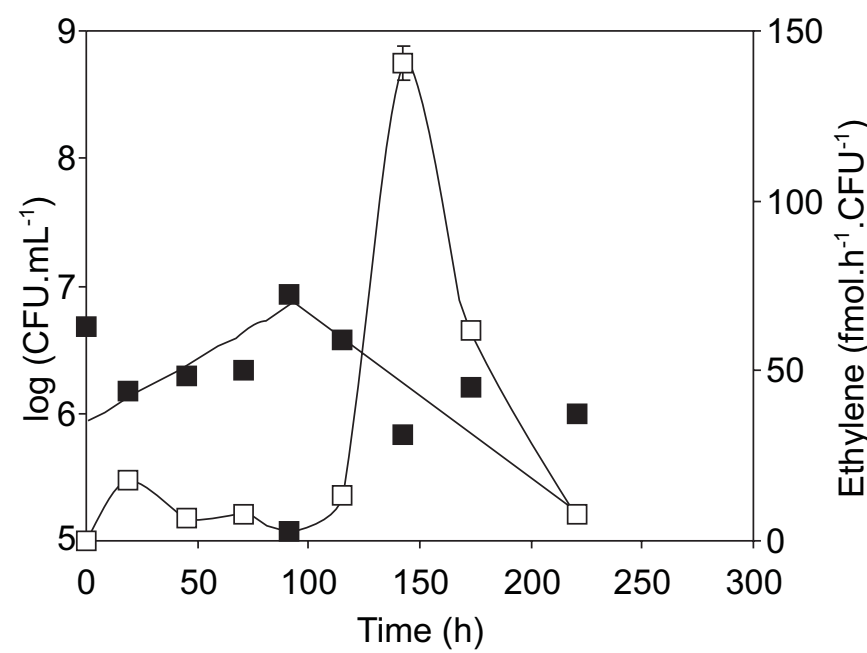

Figure 5: Effect of $40 \mathrm{mM}$ sodium thiosulphate on growth measured as CFU.mL $\mathrm{mL}^{-1}$ (closed symbols) and on specific nitrogenase activity measured as fmol.h ${ }^{-1}$.CFU ${ }^{-1}$ ethylene (open symbols) of B. derxii (condition I).

\section{DISCUSSION}

The growth and specific nitrogenase activity curves of $B$. derxii strain ICB-10 permitted us to determine both the stimulation and inhibition by each test-agent and also at what growth phase the effect occurred.

The lowest $\mathrm{pH}$ value under which $B$. derxii strain ICB-10 was able to grow ( $\mathrm{pH} 2.8$ ) was very similar to that observed by Becking (7). The results shown in Fig. 1 suggest that part of the population was unable to survive at this $\mathrm{pH}$ but that the remaining cells were still able to perform some division. Despite the low $\mu_{\max }\left(0.0198 \mathrm{~h}^{-1}\right)$ and $\mathrm{n}(3.5)$, these cells showed a stimulus of the nitrogenase activity, presenting a higher peak than the standard one during the exponential phase in condition A.
The ability to multiply at low $\mathrm{pH}$ depends on accurate responses that control the passage of protons into the cell. Pham and Burgess (16), working with purified nitrogenase from Azotobacter vinelandii, demonstrated that the enzyme was inactivated at $\mathrm{pH}$ lower than 5.0. The fact that the nitrogenase enzyme is active when the bacterial cell is in an acid environment means that propitious cytoplasmic conditions are being maintained. In order to increase the chance of surviving under the stress conditions imposed by a low $\mathrm{pH}$, the microorganisms undergo a programmed molecular response by which specific, stress-inducible proteins are synthesized. These proteins presumably act to prevent or repair the macromolecular damages caused by stress (6). The growth and specific nitrogenase activity curves at $\mathrm{pH} 4.2$ (condition D), very similar to those obtained for condition A, show that $B$. derxii strain ICB-10 isolated from an acid soil can survive at $\mathrm{pH} 4.2$ without suffering interference in either parameter measured.

The influence of aluminium on the growth of nitrogen-fixing bacteria depends on the species and on the environment: nitrogen incorporation by a strain of $A$. chroococcum was altered by $230 \mu \mathrm{M} \mathrm{Al}_{2}\left(\mathrm{SO}_{4}\right)_{3}$ at $\mathrm{pH}$ 7.1, a strain of Beijerinckia indica was affected only at $\mathrm{pH}$ 5.0, and another strain of B. mobilis did not suffer any alteration (8). This lack of susceptibility was attributed to acid tolerance. Nevertheless, the $B$. derxii tested here (Fig. 2) had its growth pattern partially affected by this metal despite being tolerant to low $\mathrm{pH}$, indicating that $\mathrm{Al}^{3+}$ susceptibility must be independent of $\mathrm{pH}$ susceptibility. Renner and Howard (20) noted that $\mathrm{Al}^{3+}$ is able to inhibit nucleotidedependent switch proteins, such as nitrogenase. However, under the tested conditions of this study, nitrogenase activity was restricted to the exponential growth phase and was not affected by the presence of aluminium (Table 1). One possible explanation for the fact that no influence of $\mathrm{Al}^{3+}$ on specific nitrogenase activity was observed may be the following: genetic and metabolic changes that occur during the stationary phase (13) probably made the cells more susceptible to the presence of aluminium. Indeed, the fact that an early death phase was observed corroborates with the above hypothesis.

Although growth of $B$. derxii strain ICB-10 may be limited by low phosphate concentration (3), higher concentrations were not propitious to its growth, reducing $\mu_{\max }$ at both $50 \mathrm{mM}$ and $100 \mathrm{mM}$ potassium phosphate and with a low $n$ at $100 \mathrm{mM}$ when compared to condition A (Fig. 3 and Table 1). Becking (8) reported that growth was proportional to the phosphate concentration up to certain levels that were lower for $B$. indica and $B$. mobilis than for A. chroococcum; a proportional decrease in growth was observed at higher phosphate concentrations. Working with Klebsiella pneumoniae, Bergersen (9) proposed that the phosphate requirements of $\mathrm{N}_{2}$-fixing systems are not higher than those of systems utilizing combined $\mathrm{N}$.

The ability of $B$. derxii strain ICB-10 to adapt to the low $\mathrm{pH}$, excess of aluminium and scarcity of phosphate that predominate 
in lateritic soils is unquestionable: growth at $\mathrm{pH} 4.2$ was similar to condition A, low alterations were observed at elevated aluminium concentrations and low phosphate concentration improved bacterial growth. In all cited situations, specific nitrogenase activity was not affected, suggesting the presence of mechanisms that simultaneously deal with these three conditions.

The comparison of still cultures (condition $\mathrm{H}$ ) showed that shaking (condition A) improved cell growth (Figs. 1 and 4). Despite the ability of $B$. derxii strain ICB-10 to produce a slime layer both under still and shaken conditions, under the conditions of this study, nitrogenase was not totally protected against the action of $\mathrm{O}_{2}(1)$. Aerobic nitrogen fixers fix nitrogen more efficiently at sub-atmospheric oxygen tension. In still cultures the gradual increase of specific nitrogenase activity to elevated values, during a phase where no growth was occurring, indicates that the lower redox potencial of the medium (21) promoted conditions for continuous nitrogenase activity.

Studies conducted with purified nitrogenase showed that sodium thiosulphate functions as an iron-protein reducing agent (10). The present investigation showed that this substance is able to affect nitrogenase activity even inside the living cell; also all the growth parameters studied were altered (Table 1 and Fig. 5). The nitrogenase activity increased 70-fold, suggesting that $\mathrm{Na}_{2} \mathrm{~S}_{2} \mathrm{O}_{3}$ may act on the cell in a manner similar to its action on the purified enzyme, increasing the reducing power available for enzyme catalysis, even though other metabolic activities had been affected (growth inhibition).

B. derxii strain ICB-10 may be differently affected by distinct environments. However, no relationship between any affected growth parameter and specific nitrogenase activity was found, suggesting that different mechanisms may be triggered depending on the environmental conditions.

Under some adverse conditions to growth $\left(\mathrm{pH} 2.8\right.$, low $\mathrm{O}_{2}$ availability, and presence of sodium thiosulphate), stimulation of specific nitrogenase activity occurred. This effect is probably related to the enzymatic regulation resulting in an increased synthesis or stimulation of nitrogenase activity. When a bacterial population is affected by a certain substance, an effective metabolic regulation is possibly triggered in order to preserve the particularly relevant molecules under such conditions. In Anabaena doliolum, copper caused different effects like a decrease of about $50 \%$ in specific growth rate, dry weight and lipid concentration, but only a $12 \%$ decrease in protein concentration and stimulation of the ability to synthesize pigments (19). However, Nostoc linckia, under cadmium stress, presented delayed nitrogenase activity proportional to the agent concentration (12).

The present report shows that certain environmental factors which depress growth may stimulate nitrogenase during the exponential, stationary and death growth phases. The stimulus may be very high during the stationary or death phases, conditions in which bacteria are commonly found in the environment. Preservation of nitrogenase activity under these environmental conditions emphasizes the importance of this enzyme for nitrogen-fixing organisms.

\section{ACKNOWLEDGEMENTS}

The authors thank FUNDAP and CNPq for undergraduate fellowships.

\section{RESUMO}

\section{A atividade da nitrogenase de Beijerinckia derxii é preservada sob condições diversas para seu crescimento}

Os parâmetros utilizados para se avaliar a ação de diferentes fatores ambientais sobre Beijerinckia derxii foram curvas de crescimento e medidas de atividade específica de nitrogenase. As condições estudadas foram: a) meios com os valores de $\mathrm{pH}$ 2,5, 2,8, 4,2 e 5,7; b) meio suplementado com $230 \mathrm{mM}$ de sulfato de alumínio; c) meio com as concentrações de fosfato de potássio: $50 \mathrm{mM}$ and $100 \mathrm{mM}$; d) culturas agitada e estacionada; e) meio suplementado com $40 \mathrm{mM}$ de tiossulfato de sódio. $\mathrm{O}$ crescimento e a atividade da nitrogenase foram muito similares em meio com pH 4,2 e 5,7 (condição padrão). Em pH 2,5 não se observou crescimento. As seguintes condições provocaram alterações no perfil da curva de crescimento ou na atividade da enzima ou ambos: $\mathrm{pH}$ 2,8 (diminuição do número inicial de UFC, redução da máxima velocidade especifica de crescimento, redução no número de gerações e estímulo na atividade da nitrogenase), presença de alumínio (fase de declínio precoce), $50 \mathrm{mM} \mathrm{PO}_{4}{ }^{3-}$ (redução da velocidade especifica de crescimento máxima), $100 \mathrm{mM} \mathrm{PO}_{4}{ }^{3-}$ (redução da velocidade especifica de crescimento máxima e no número de gerações e fase de declínio precoce), baixa disponibilidade de $\mathrm{O}_{2}$ (estímulo na atividade da nitrogenase) e presença de tiossulfato (redução da velocidade especifica de crescimento máxima, elevado estímulo na atividade da nitrogenase e fase de declínio precoce). Ocorreu uma variação no perfil das curvas de crescimento em resposta à ação dos fatores ambientais. A atividade da nitrogenase foi sempre mantida, mesmo quando o crescimento foi reduzido.

Key words: Beijerinckia, nitrogenase, fixação de nitrogênio, crescimento, fatores ambientais.

\section{REFERENCES}

1. Barbosa, H.R.; Struckel, Y.F. Slime production by Beijerinckia derxii effects of cultural conditions. Soil Biol. Biochem., 17: 731-732, 1985.

2. Barbosa, H.R.; Struckel, Y.F.; Almeida-Filho, R.C. Nitrogenase activity of a negative nitrate reductase Beijerinckia derxii grown in a carbon less medium. Rev. Microbiol., 17: 264-269, 1986. 
3. Barbosa, H.R.; Garcia-Canedo, A.M.G. A concentração de fosfato no crescimento de Beijerinckia derxii cultivada com $\mathrm{N}_{2}$ ou $\mathrm{NH}_{4}$ como fonte de nitrogênio. R. Bras. Ci. Solo, 13: 399-402, 1989.

4. Barbosa, H.R.; Alterthum, F. The role of extracellular polysaccharide in cell viability and nitrogenase activity of Beijerinckia derxii. Can. J. Microbiol., 38: 986-988, 1992.

5. Barbosa, H.R.; Rodrigues, M.F.A.; Campos, C.C.; Chaves, M.E., Nunes, I.; Juliano, Y.; Novo, N.F. Counting of viable clusterforming and non cluster-forming bacteria: a comparison between the drop and the spread methods. J. Microbiol. Methods, 22: 3950, 1995 .

6. Bearson, S.; Bearson, B.; Foster, J.W. Acid stress responses in enterobacteria. FEMS Microbiol. Lett., 147: 173-180, 1997.

7. Becking, J.H. Studies on nitrogen-fixing bacteria of the genus Beijerinckia I. Geographical and ecological distribution in soils. Plant Soil., XIV: 49-81, 1961.

8. Becking, J.H. Studies on nitrogen-fixing bacteria of the genus Beijerinckia II. Mineral nutrition and resistance to high levels of certain elements in relation to soil type. Plant Soil., XIV: 297-322, $1961 b$.

9. Bergersen, J.F. The effects of phosphate concentration on $\mathrm{N}_{2}$ and $\mathrm{NH}_{4}$-grown Klebsiella pneumoniae. J. Gen. Microbiol., 84: 412414, 1974.

10. Burris, R.H., Nitrogenases. J. Biol. Chem., 266: 9339-9342, 1991.

11. Dalton, H.; Postgate J.R. Effect of oxygen on growth of Azotobacter chroococcum in batch and continuous cultures. J. Gen. Microbiol., 54: 463-473, 1969

12. Husaini, Y.; Rai, L.C. Studies on nitrogen and phosphorus metabolism and the photosynthetic electron transport system of Nostoc linckia under cadmium stress. J. Plant Physiol., 138: 429435, 1991
13. Kolter, R.; Siegele, D.A.; Tormo, A. The stationary phase of the bacterial life cycle. Ann. Rev. Microbiol., 47: 855-874, 1993.

14. Langenbach, T.; Nascimento, A.; Sarpa, M. Influence of heavy metals on nitrogen fixation and growth of Azospirillum strains. Rev . Latamer. Microbiol., 30: 139-142, 1988.

15. Malavolta, E.; Sarruge, J.R.; Bittencourt, V.C. Toxidez de alumínio e de manganês. In: VI Simpósio sobre o Cerrado. São Paulo, Ed. Universidade de São Paulo, p.275-301, 1976.

16. Pham, D.N.; Burgess, B.K. Nitrogenase reactivity: effects of $\mathrm{pH}$ on substrate reduction and $\mathrm{CO}$ inhibition. Biochemistry, 32: 1372513731, 1993.

17. Pirt, S.J. Principles of microbial cell cultivation. Wiley, New York., $1975,274 \mathrm{p}$

18. Postgate, J.R., Nitrogen Fixation. Cambridge University Press, Cambridge, 1998, 112p.

19. Rai, L.C.; Mallick, N.; Singh, J.B.; Kumar , H.D. Physiological and biochemical characteristics of a copper tolerant and a wild type strain of Anabaena doliolum under copper stress. J. Plant Physiol., 138: 68-74, 1991

20. Renner, K.A.; Howard, J.B. Aluminum fluoride inhibition of nitrogenase: stabilization of a nucleotide center dot Fe-protein center dot MoFe-protein complex. Biochemistry, 35: 5353-5358, 1996.

21. Trolldenier, G. Influence of some environmental factors on nitrogen fixation in the rhizosphere of rice. Plant Soil, 47: 203-217, 1977.

22. Trivedi, N.C.; Tsuchiya, H.M. Microbial mutualism in leaching of $\mathrm{Cu}-\mathrm{Ni}$ sulfide concentrate. Intern. J. Min. Processing, 2: 1-14, 1975.

23. Turner, G.L.; Gibson A.H. Measurement of nitrogen fixation by indirect means. In: Methods for Evaluating Biological Nitrogen Fixation (F.J. Bergersen, Ed.), Wiley, Chichester, 1980, p.111-138.

24. Tsuchiya, H.M.; Trivedi, N.C.; Schuler, M.L. Microbial mutualism in ore leaching. Biotech. Bioeng., XVI 991-995, 1974. 